\title{
PENGARUH RESTRUKTURISASI HUTANG, REPUTASI KAP, LIKUIDITAS DAN OPINION SHOPPING TERHADAP GOING CONCERN
}

\author{
Aprillia Nur Azizah \\ Universitas Negeri Surabaya, aprillia.17080694047@mhs.unesa.ac.id
}

\begin{abstract}
ABSTRAK
Tujuan dari penelitian ini ialah untuk menganalisis dampak dari restrukturisasi hutang, reputasi KAP, likuiditas, dan opinion shopping pada opini audit going concern perusahaan transportasi yang terdaftar di Bursa Efek Indonesia (BEI). Sumber sampel penelitian ini dikumpulkan dari Bursa Efek Indonesia (BEI) dengan mengunjungi website www.idx.co.id. Seluruh perusahaan transportasi yang terdaftar di Bursa Efek Indonesia (BEI) periode 2015-2019 menjadi populasi dalam penelitian ini. Jumlah perusahaan transportasi yang dijadikan sampel dalam penelitian ini adalah 15 perusahaan dengan menggunakan laporan tahunan selama 5 tahun terakhir. Berdasarkan metode purposive sampling maka jumlah sampel dalam penelitian ini adalah 150 sampel. Teknik regresi logistik digunakan dalam penelitian ini. Data sampel diolah dengan menggunakan SPSS 25 dimana hasil penelitian menunjukkan bahwa variabel restrukturisasi hutang dan opinion shopping berdampak pada opini audit going concern. Sedangkan variabel reputasi dan likuiditas KAP tidak berdampak pada opini audit going concern. Dalam sektor transportasi ini, aset tetap perusahaan lebih besar dari jumlah total aset lancar yang dimilikinya. Oleh karena itu, sebagian besar kontrak yang ditandatangani oleh perusahaan lebih bersifat jangka panjang daripada jangka pendek. Sehingga likuiditas tidak berpengaruh dan restrukturisasi hutang secara keseluruhan berpengaruh pada pemberian opini audit going concern.
\end{abstract}

Kata Kunci: Restrukturisasi Hutang, Reputasi KAP, Likuiditas, Opinion Shopping, Going Concern

\begin{abstract}
The purpose of this research is to analyze the affect of debt restructuring, the reputation of public accountant firms, liquidity, and opinion shopping towards going concern audit opinion on transportation companies listed on the Indonesia Stock Exchange (IDX). The sample resource of this research was gathered from the Indonesia Stock Exchange (IDX) by accessing the website www.idx.co.id. All transportation companies listed on the Indonesia Stock Exchange (IDX) in the period of 2015-2019 became the population in this research. The number of transportation companies sampled in this research was 15 companies using their past 5 years' annual report. According to the purposive sampling method, the total sample of this research was 150 samples. Logistic regression techniques were used in this research. The sample data were processed using SPSS 25 where the results show that debt restructuring and opinion shopping variables affect the going concern audit opinion. Meanwhile, the KAP reputation and liquidity variables don't affect the going concern audit opinion. In this transportation sector, fixed assets are greater than the total current assets of the company. Therefore, most of the contracts signed by companies are more long term than short term. So that liquidity has no effect and overall debt restructuring has an effect on giving going concern audit opinions.
\end{abstract}

Keywords: Debt Restructuring, Reputation of Public Accountant Firms, Liquidity, Opinion Shopping, Going Concern 
Naskah diterima : 12-04-2021, Naskah dipublikasikan : 30-11-2021

\section{PENDAHULUAN}

Standar Audit (SA) 570 merupakan pedoman mengenai berbagai hal atau tanggung jawab yang harus diperhatikan auditor dalam merumuskan opini kelangsungan usaha sebuah perusahaan atau sering disebut opini going concern. Opini going concern merupakan opini yang dikeluarkan auditor untuk mengevaluasi apakah terdapat kesanksian tentang kemampuan perusahaan dalam mempertahankan kelangsungan usahanya (IAPI, 2013). Di Indonesia masih banyak perusahaan yang diragukan kelangsungan usahanya, sehingga mendorong BEI menetapkan early warning procedure seperti suspensi dan delisting (Kontan.co.id, 2019). Sejak tahun 2015 hingga 2019 terdapat 21 perusahaan delisting dan 47 perusahaan mengalami suspensi sepanjang tahun tersebut (CNBC Indonesia.com, 2020). Pada tahun 2018, PT Bursa Efek Indonesia mengeluarkan surat edaran nomor SE-00001/BEI/12-2018 tentang pemberian notasi khusus bagi perusahaan yang bermasalah.

Suatu perusahaan berdiri pasti memiliki visi dan misi yang sama dalam hal menghasilkan keuntungan ataupun profit dalam bidang usahanya. Akan tetapi, adanya suatu perusahaan tersebut tidak dapat lepas dari pengaruh dinamis area perusahaan baik secara internal ataupun eksternal yang berakibat pada persaingan antar perusahaan. Hal tersebut dapat memunculkan suatu kecenderungan perusahaan mempunyai kesulitan dalam pelaksanaan visi serta misi yang paling mendasar, yaitu kelangsungan hidup perusahaannya (going concern). Hal ini menimbulkan besar kemungkinan praktik- praktik illegal sebagai akibat dari kesulitan yang mengancam kelangsungan hidup perusahaan.

Tahun 2015, perusahaan pada sektor transportasi telah mengalami perubahan yang signifikan terutama pada transportasi darat (taksi konvensional) dikarenakan maraknya penggunaan Go-jek dan Grab sebagai layanan transportasi darat (taksi online) secara lebih modern dan praktis (Detik.com, 2017). Hal ini dapat berdampak pada kelangsungan usaha perusahaan transportasi ketika tidak mampu berinovasi dan menyesuaikan model bisnisnya dengan perkembangan teknologi, maka perusahaan akan terancam mengalami kemunduran bisnis (WartaEkonomi.co.id, 2019). Sebagai contoh, PT Blue Bird Tbk (idx code: BIRD) optimis bisa bersaing dengan layanan taksi online semacam Grab dan Gojek. Industri taksi ini yakin ia dapat memenangkan persaingan dari perbandingan kualitas layanan. Hal ini diperkuat dengan statement oleh Chief Information Officer PT Blue Bird Tbk yang pernah menyinggung kerjasama Blue Bird dengan Gojek, bahwasanya Blue Bird terbantu dengan jangkauan konsumen yang luas. Sebaliknya, Gojek terbantu dengan ketersediaan armada Blue Bird yang besar (CNN Indonesia.com, 2019).

Akhir tahun 2015, terdapat dampak pada transportasi umum terutama pada perusahaan transportasi yang menyediakan jasa logistik dengan maraknya online shopping dengan menggunakan e-commerce seperti Shopee, Lazada, Tokopedia, Bukalapak, dan sebagainya. Hal ini tentu berpengaruh terhadap pendapatan yang diterima oleh perusahaan. Adapun data terkait pendapatan rata-rata dari sektor transportasi mulai dari tahun 2015-2018 sebagai berikut. 


\section{JURNAL AKUNTANSI, Vol. 10, No. 2, November (2021)}

Tabel 1. Rata-Rata Pendapatan Sektor Transportasi Tahun 2015-2019

\begin{tabular}{|c|c|c|}
\hline Tahun & Total perusahaan & Rata-rata pendapatan \\
\hline 2015 & 32 & Rp 2.412.905.707.557 \\
\hline 2016 & 32 & Rp 2.096.158.534.306 \\
\hline 2017 & 32 & Rp 2.028.660.025.631 \\
\hline 2018 & 39 & Rp 3.389.892.334.634 \\
\hline 2019 & 42 & $\operatorname{Rp} 2.465 .081 .861 .133$ \\
\hline
\end{tabular}

Sumber : Laporan Keuangan Perusahaan Transportasi yang terdaftar di BEI (www.idx.co.id)

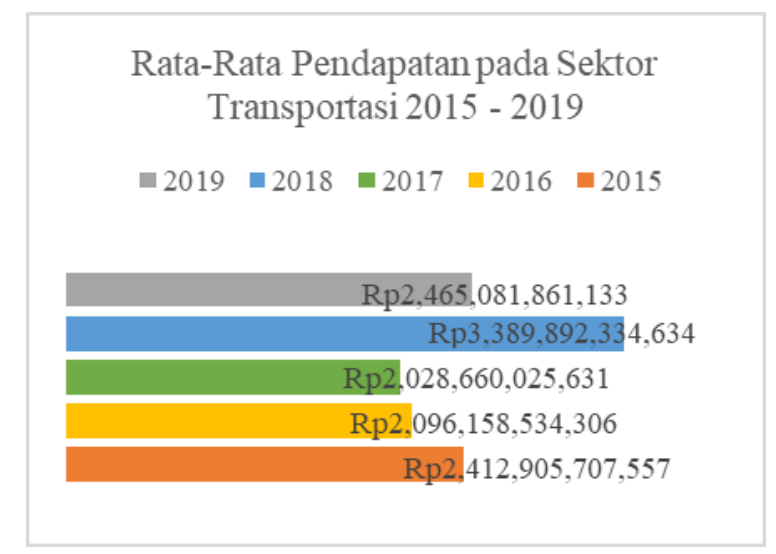

Gambar 1. Grafik Rata-Rata Pendapatan Sektor Transportasi Tahun 2015-2019

Tabel 1 dan gambar 1 menunjukkan bahwa sektor transportasi telah mengalami perkembangan yang cukup signifikan sejak tahun 2015 hingga 2018. Pada tahun 2016 dan 2017 terjadi penurunan pendapatan di 5 perusahaan yaitu BIRD, TAXI, WEHA, MIRA, dan ZBRA yang disebabkan minimnya persiapan menghadapi tantangan hadirnya transportasi online, walau sempat mengalami penurunan pendapatan perusahaan dan mendapati opini audit going concern dari auditornya, perusahaan-perusahaan tersebut terus melakukan banyak cara agar dapat settle sehingga masih dapat bertahan hingga saat ini. Tahun 2018 perusahaan transportasi laut telah mengalami kenaikan pendapatan yang tinggi hal ini dikarenakan adanya 7 perusahaan transportasi laut (pelayaran) yang melakukan ekspansi dan juga melakukan kerjasama dengan perusahaan yang sejenis untuk meningkatkan pendapatannya.

Berdasarkan fenomena tersebut, opini auditor sangat dibutuhkan. Auditor harus mempertimbangkan dampak atas kondisi yang terjadi dalam perusahaan ketika mengeluarkan opini going concern (IAPI, 2013). Maka dari itu, auditor dituntut untuk dapat mengkomunikasikan secara rinci dan jelas dengan manajemen perusahaan untuk mengetahui segala aspek mengenai perusahaan yang diaudit agar dapat memberikan opini yang sesuai terkait kondisi perusahaan. Dalam hal ini penulis mencari tahu apa saja aspek-aspek yang memberikan dampak suatu perusahaan sehingga didapati opini going concern dari auditor eksternalnya.

Hasil penelitian Maharani (2016) memaparkan bahwa diberikannya opini audit going concern tidak terdampak oleh restrukturisasi hutang. Ini dikarenakan restrukturisasi hutang tidak dapat menjadi penyebab utama auditor untuk mengeluarkan opini audit going concern, 
namun terdapat aspek lain dan aspek keuangan lain yang terlibat harus diperhatikan dan dipertimbangkan.

Penelitian Tandungan (2016) dan Laksmiati \& Atiningsih (2018) menyatakan pemberian opini audit going concern tidak terdampak oleh reputasi KAP. Output uji ini bertentangan dengan riset dari Krissindiastuti \& Rasmini (2016) dan Elmawati, dkk (2014) memaparkan bahwa opini audit going concern dapat terdampak oleh reputasi sebuah KAP.

Hasil penelitian Anita (2017) dan Made dkk (2017) ditemukan bahwa opini audit going concern tidak terdampak oleh likuiditas perusahaan, sedangkan dalam penelitian Trisnawati (2014) menyatakan bahwa likuiditas (dalam hal ini diukur dengan (CR) current ratio) memiliki dampak yang signifikan pada didapatinya opini audit going concern.

Output penelitian Syahputra \& Yahya (2017) memaparkan bahwa diberikannya opini audit going concern secara signifikan dapat dipengaruhi oleh praktik opinion shopping. Sedangkan, menurut Putra \& Suzan (2013) menyatakan bahwa pemberian opini audit going concern tidak dapat dipengaruhi oleh praktik opinion shopping.

Hasil-hasil penelitian sebelumnya masih terdapat hasil yang tidak konsisten, serta pengukuran dari variabel-variabel yang diteliti. Sehingga, peneliti tertarik mempelajari kembali apa saja aspek yang dapat memberi dampak dikeluarkannya opini audit going concern. Sehingga tujuan penelitian ini ialah untuk menguji pengaruh restrukturisasi hutang, reputasi KAP, likuiditas, dan opinion shopping terhadap penerimaan opini audit going concern. Sektor Transportasi yang terdaftar di BEI 2015-2019 menjadi sektor yang diamati oleh peneliti.

\section{KAJIAN LITERATUR}

\section{Teori Agensi (Agency Theory)}

Jensen \& Meckling (1976) menerangkan bahwasanya teori agensi merupakan jalinan keagenan sesuatu kontrak, yang mana satu individu atau lebih memerlukan pihak yang lain (agen) untuk mengerjakan sebagian pekerjaan atas nama prinsipal, yang melibatkan sebagian kekuasaan atau otoritas dalam pengambilan keputusan pada agen. Dengan adanya kepentingan kedua belah pihak yang berbeda, sehingga konflik kepentingan kerap berlangsung antara agen sebagai pihak yang diberikan kekuasaan atau otoritas untuk mengurus dan menjalankan perusahaan dengan principal. Karena itu perlu adanya pihak ketiga independen yang dapat mempelajari sekaligus menganalisa laporan keuangan yang dibuat oleh manajemen dan memberi assurance serta opini terhadap laporan keuangan tersebut, yakni seorang auditor.

\section{Teori Sinyal (Signaling Theory)}

Teori signaling sangat berguna untuk menjelaskan sikap dua kelompok (individu atau entitas) ketika mereka memiliki jalan masuk ke informasi data yang senjang. Umumnya, terdapat satu kelompok (insider) harus memilih apa dan bagaimana penyampaian sinyal informasi itu, dan kelompok lainnya (outsider) harus memilih bagaimana cara menafsirkan sinyal tersebut (Connelly et al., 2011). Ketika sinyal yang diberikan oleh insider dianggap sebagai good news, maka investor atau pihak outsider akan menanggapi dengan melakukan investasi, begitupun sebaliknya. Dengan begitu, dalam berbagai literatur manajemen, termasuk manajemen strategis, manajemen sumber daya manusia, dan kewirausahaan, teori sinyal ini menempati posisi yang sangat penting. Korelasi antara teori signaling dengan opini going concern yaitu opini audit merupakan sinyal mengenai kinerja perusahaan dan digunakan untuk memprediksi potensi keberlangsungan entitas di masa depan. 


\section{JURNAL AKUNTANSI, Vol. 10, No. 2, November (2021)}

\section{Teori Atribusi (Attribution Theory)}

Heider (1958) dalam Handke \& Barthaue (2019) mengargumentasikan teori atribusi ialah teori yang berkaitan dengan sikap seseorang. Teori ini menerangkan tentang proses bagaimana kita memastikan faktor serta motif seseorang melakukan suatu hal. Teori ini merujuk pada bagaimana cara seseorang menafsirkan sikap dirinya sendiri ataupun orang lain yang ditegaskan dari dalam (misalnya watak, kepribadian, perilaku, dan lain-lain) atau dari luar (misalnya tekanan suasana atau kondisi tertentu yang akan membagikan pengaruh terhadap perilaku seseorang). Teori tersebut erat kaitannya dengan perilaku seorang auditor dalam menjalankan profesinya (atau sering disebut sebagai independensi), utamanya dalam memberikan opini serta professional judgement terhadap review atas laporan keuangan maupun opini going concern dari manajemen perusahaan klien.

\section{Opini Audit Going Concern}

Opini going concern merupakan opini yang dikeluarkan auditor untuk mengevaluasi apakah terdapat kesanksian tentang kemampuan perusahaan dalam mempertahankan kelangsungan usahanya (IAPI, 2013). Dari pengertian tersebut dapat disimpulkan bahwa opini auditor sangat dibutuhkan untuk sebuah perusahaan, terutama perusahaan yang terdaftar di BEI. Auditor harus mempertimbangkan dampak atas kondisi yang terjadi dalam perusahaan ketika mengeluarkan opini going concern (IAPI, 2013). Maka dari itu, auditor dituntut untuk dapat mengkomunikasikan secara rinci dan jelas dengan manajemen perusahaan untuk mengetahui segala aspek mengenai perusahaan yang diaudit agar dapat memberikan opini yang sesuai terkait kondisi perusahaan. Dalam hal ini penulis mencari tahu apa saja aspek-aspek yang memberikan dampak suatu perusahaan sehingga didapati opini going concern dari auditor eksternalnya.

\section{Restrukturisasi Hutang}

Menurut Peraturan OJK RI Nomor 11/POJK.03/2015 dijelaskan bahwa Restrukturisasi Kredit adalah upaya perbaikan yang dilakukan Bank dalam kegiatan perkreditan terhadap debitur yang mengalami kesulitan untuk memenuhi kewajibannya. Dapat disimpulkan bahwa restrukturisasi hutang merupakan salah satu upaya yang dapat dilakukan oleh manajemen perusahaan untuk mengungkap rencana manajemen dalam menjaga kondisi perusahaan agar terhindar dari pemberian opini audit going concern oleh auditornya. Restrukturisasi hutang sendiri biasa dilakukan ketika suatu perusahaan mengalami kesulitan dalam membayarkan kewajibannya pada tanggal jatuh tempo. Restrukturisasi ini dapat dilihat dari catatan atas laporan keuangan perusahaan pada bagian hutang, apakah perusahaan tersebut mengalami kesulitan untuk melunasi kewajibannya dalam waktu yang telah ditentukan ataukah melakukan restrukturisasi hutang untuk menyelamatkan operasional usahanya.

\section{Reputasi KAP}

Menurut KBBI, reputasi merupakan suatu perbuatan atau sikap yang menjadi penyebab mendapatkan nama baik. Reputasi KAP merupakan seberapa baik kantor akuntan publik tersebut dalam menjalankan standar, kode etik, dan peraturan yang berlaku. KAP yang bereputasi diartikan sebagai KAP yang patuh dan tidak pernah terlibat atau terkena sanksi atas tindakannya yang melanggar standar, kode etik, maupun aturan. Kepercayaan publik terhadap kinerja suatu KAP menunjukkan reputasi KAP. Maka dari itu, KAP bertanggung jawab untuk tetap menjaga kepercayaan publik dan menjaga nama baik KAP dengan mengeluarkan opini yang sesuai dengan keadaan perusahaan yang sebenarnya. Oleh sebab itu pula, KAP dengan reputasi dapat menyediakan kualitas audit yang lebih baik, termasuk dalam mengungkapkan masalah going concern. 


\section{Likuiditas}

Likuiditas mencerminkan kemampuan perusahaan dalam menyelesaikan kewajiban jangka pendeknya dengan menggunakan aktiva lancar yang dimiliki. Menurut Trisnawati (2014) rasio likuiditas (liquidity ratio) merupakan rasio yang menggambarkan kemampuan perusahaan dalam memenuhi kewajiban (utang) jangka pendek. Oleh karenanya rasio likuiditas merupakan perbandingan kewajiban jangka pendek dengan aktiva lancar atau biasa disebut dengan CR (current ratio) dalam perusahaan. Artinya apabila perusahaan ditagih, perusahaan akan mampu untuk memenuhi utang tersebut terutama utang yang sudah jatuh tempo. Dengan kata lain, rasio likuiditas berfungsi untuk menunjukkan atau mengukur kemampuan perusahaan dalam memenuhi kewajibannya yang sudah jatuh tempo. Semakin tinggi likuiditas yang dimiliki semakin besar pula kemampuan perusahaan dalam membayar kewajiban jangka pendeknya, begitupun sebaliknya.

\section{Opinion Shopping}

Opinion shopping didefinisikan oleh Securities and Exchange Commission sebagai kegiatan mencari auditor yang mau mendukung perlakuan akuntansi yang dilakukan oleh manajemen untuk mencapai tujuan pelaporan keuangan. Perusahaan biasanya melakukan pergantian auditor (auditor switching) untuk menghindari penerimaan opini audit going concern dengan dua cara, yaitu (1) perusahaan dapat mengancam melakukan pergantian auditor (2) ketika auditor tersebut independen, perusahaan akan memberhentikan auditor yang cenderung memberikan opini audit going concern.

Padahal, kewajiban mengenai pergantian Akuntan Publik maupun Kantor Akuntan Publik (KAP) telah diatur Pemerintah Indonesia dengan dikeluarkannya Keputusan Menteri Keuangan RI bahwasanya dalam Peraturan OJK No. 13/POJK.03/2017, yang menegaskan bahwa perusahaan atau entitas (yang dikecualikan dalam PP No. 20 Tahun 2015) wajib membatasi penggunaan jasa audit atas informasi keuangan historis tahunan dari Akuntan Publik yang sama paling lama untuk periode audit selama 3 tahun buku pelaporan secara berturut-turut. Sedangkan, pada Peraturan Pemerintah No. 20 Tahun 2015 dijelaskan bahwa pemberian jasa audit atas informasi keuangan historis terhadap suatu entitas tertentu oleh seorang Akuntan Publik dibatasi paling lama untuk 5 tahun buku berturut-turut, dimana entitas yang dimaksud ialah entitas Industri yang terdaftar pada Pasar Modal, Bank umum, Dana Pensiun, Perusahaan asuransi atau reasuransi, dan BUMN.

Pergantian auditor yang dilakukan oleh manajemen perusahaan tanpa mempertimbangkan masa atau tenur perikatan yang sesuai dengan undang-undang inilah yang disebut opinion shopping. Tujuan pelaporan dalam opinion shopping untuk meningkatkan (memanipulasi) hasil operasi atau kondisi keuangan perusahaan. Opinion shopping dapat memberikan dampak negatif pada perusahaan. 


\section{JURNAL AKUNTANSI, Vol. 10, No. 2, November (2021)}

\section{PENGEMBANGAN HIPOTESIS}

\section{Kerangka Berpikir}

Dengan hadirnya Go-jek dan Grab atau taksi online di tengah-tengah masyarakat
mengakibatkan adanya ancaman bagi taksi konvensional yang sudah lebih dulu
hadir di masyarakat. Selain itu, maraknya penggunaan platform e-Commerce
mengakibatkan perubahan lifestyle masyarakat di Indonesia. Dari yang semula
berbelanja datang ke toko menjadi online shopping. Hal ini jelas berpengaruh
terhadap kinerja perusahaan di bidang transportasi terutama yang menyediakan
jasa logistik. Fenomena tersebut, dapat diketahui bahwa perusahaan transportasi
telah mengalami banyak revolusi, hal ini berpangaruh terhadap keberlangsungan
usaha dari perusahaan itu sendiri. Peran auditor sangatlah penting karena dari
penugasan yang dilakukan dapat memberikan opini going concern yang dapat
sesuai dengan perusahaan klien dan dapat membuat stakeholder percaya bahwa
perusahaan tersebut dapat mempertahankan kegiatan usahanya dan terus berfungsi
sebagai entitas bisnis.
sebagai entitas bisnis.

\begin{tabular}{|c|c|}
\hline Kajian Teori: & Penelitian terdahulu: \\
\hline $\begin{array}{l}\text { 1. Teori Agency } \\
\text { 2. Teori Signalling } \\
\text { 3. Teori Atribusi }\end{array}$ & $\begin{array}{l}\text { 1. Nugroho et al. (2017) } \\
\text { 2. Elsa Devi Laksmiati et al. (2018) } \\
\text { 3. Debby Tandungan (2016) }\end{array}$ \\
\hline $\begin{array}{l}\text { 4. Opini Audit Going Concern } \\
\text { 5. Restrukturisasi hutang } \\
\text { 6. Reputasi KAP } \\
\text { 7. Likuiditas } \\
\text { 8. Opinion Shopping } \\
\end{array}$ & $\begin{array}{l}\text { 4. Krissindiastuti \& Rasmini (2016) } \\
\text { 5. Maharani (2016) } \\
\text { 6. Trisnawati (2014) } \\
\text { 7. Putra \& Suzan (2013) } \\
\text { 8. Martio \& Amir (2014) }\end{array}$ \\
\hline $\begin{array}{l}\text { Variabel independen: } \\
\text { x1· Restruktturisasi hutang }\end{array}$ & $\begin{array}{c}\text { Variabel dependen: } \\
\mathrm{Y} \text { : Opini Audit Going Concern }\end{array}$ \\
\hline $\begin{array}{l}\text { X2: Reputasi KAP } \\
\text { X3: Likuiditas } \\
\text { X4: Opinion Shopping }\end{array}$ & \\
\hline
\end{tabular}

Gambar 2. Kerangka Berpikir

\section{Pengaruh Restrukturisasi Hutang terhadap Opini Audit Going Concern}

Restrukturisasi hutang merupakan satu dari banyaknya upaya yang dilakukan oleh manajemen perusahaan demi mempertahankan kelangsungan usaha suatu perusahaan dalam keadaan dimana perusahaan tersebut tidak dapat melunasi kewajibannya sesuai dengan jatuh tempo. Hal ini dikarenakan perusahaan yang melakukan restrukturisasi hutang besar kemungkinan sedang mengalami financial distress, dimana nilai aktiva yang dimanfaatkan untuk mengoperasikan atau mencetak arus kas mengalami penurunan secara signifikan. Sehingga hal ini dapat mengindikasikan adanya gangguan kelangsungan hidup perusahaan. Maharani (2016) memaparkan bahwa diberikannya opini audit going concern terdampak oleh restrukturisasi hutang. Karena hal ini pula, berimbas pada perolehan opini audit going concern oleh auditor. Sebab itu, rumus hipotesis yang ditetapkan adalah sebagai berikut:

\section{H1 : Restrukturisasi Hutang berpengaruh terhadap opini audit going concern}

\section{Pengaruh Reputasi KAP terhadap Opini Audit Going Concern}

Reputasi KAP dapat diartikan sebagai nama baik sebuah KAP yang dapat mencerminkan kualitas kinerja KAP serta meningkatkan value sebuah KAP di stakeholder (Odanga, 2016). Reputasi KAP ini memang penting, karena perihal tersebut dapat meningkatkan kualitas audit serta kepercayaan dari klien (manajemen perusahaan) atas pertanggungjawaban opini yang akan dikeluarkan oleh auditornya. KAP yang bereputasi 
diartikan sebagai KAP yang patuh dan tidak pernah terlibat atau terkena sanksi atas tindakannya yang melanggar standar, kode etik, maupun aturan. Saat ini, hampir seluruh perusahaan yang terdaftar di BEI diaudit oleh KAP yang berafiliasi asing, sehingga dalam penelitian ini peneliti mengukur reputasi sebuah KAP berdasarkan dari apakah ia pernah terlibat dalam suatu kasus yang dikarenakan adanya pelanggaran standar, kode etik, ataupun peraturan yang mengakibatkan terkenanya sanksi. Auditee berkeyakinan bahwa auditor yang bereputasi juga akan mampu memberikan kualitas audit yang baik dan dapat memberikan opini berdasarkan kondisi perusahaan. Krissindiastuti \& Rasmini (2016) dan Elmawati dkk (2014) juga memaparkan bahwa opini audit going concern dapat terdampak oleh reputasi sebuah KAP. Maka dibuatlah rumus hipotesis sebagai berikut:

\section{H2 : Reputasi KAP berpengaruh terhadap opini audit going concern}

\section{Pengaruh Likuiditas terhadap Opini Audit Going Concern}

Pada umumnya, likuiditas dapat mengindikasikan kapabilitas perusahaan dalam menggunakan aset lancarnya untuk menyelesaikan hutang jangka pendeknya. Likuiditas biasa diartikan sebagai current ratio dalam perusahaan. Semakin tinggi likuiditasnya, semakin besar pula kapabilitas perusahaan untuk melunasi liabilitas jangka pendeknya, begitu pula sebaliknya. Perusahaan dengan rasio likuiditas yang tinggi telah menampilkan kesanggupan untuk melunasi pinjaman jangka pendek pada saat jatuh tempo, dan akhirnya auditor tidak akan mengeluarkan opini audit going concern atas suatu perusahaan yang sanggup melangsungkan kinerja perusahaan untuk masa berikutnya. Penelitian Trisnawati (2014) pun menyatakan bahwa likuiditas (dalam hal ini diukur dengan (CR) current ratio) memiliki dampak yang signifikan pada didapatinya opini audit going concern. Sehingga rumusan hipotesis yang dibentuk sebagai berikut:

\section{H3 : Likuiditas berpengaruh terhadap opini audit going concern}

\section{Pengaruh Opinion Shopping terhadap Opini Audit Going Concern}

Lazimnya sebuah perusahaan akan mengganti auditor untuk menyingkir dari penerimaan opini audit going concern. Karena hal ini perusahaan biasanya mengakhiri masa perikatan dengan auditornya karena auditor tidak memenuhi ekspektasi yang diinginkan oleh perusahaan dalam mengeluarkan opini atas laporan keuangan. Oleh karena itu perusahaan akan mengganti auditornya sebelum masa atau tenur perikatan yang telah ditetapkan oleh undangundang dengan auditor yang mau memberi opini yang memenuhi ekspektasi yang diinginkan oleh perusahaan tersebut (Stanišić et al., 2014). Sehingga, apabila perusahaan tidak lagi mendapati opini audit going concern setelah mengganti auditornya, maka perusahaan tersebut dinilai berhasil melakukan opinion shopping. Penelitian terdahulu Syahputra \& Yahya (2017) memaparkan bahwa diberikannya opini audit going concern secara signifikan dapat dipengaruhi oleh praktik opinion shopping. Melalui uraian tersebut, penulis merumuskan hipotesis sebagai berikut:

\section{H4 : Opinion shopping berpengaruh terhadap opini audit going concern}

\section{METODE PENELITIAN}

Penelitian ini merupakan penelitian kuantitatif. Laporan tahunan perusahaan sektor transportasi yang terdaftar di BEI periode tahun 2015-2019 digunakan sebagai data dalam penelitian ini. 


\section{JURNAL AKUNTANSI, Vol. 10, No. 2, November (2021)}

\section{Populasi dan Sampel}

Teknik purposive sampling merupakan teknik yang diaplikasikan dalam penelitian ini. Berikut ini tabel penyajian hasil pemilihan sampel:

Tabel 2. Pemilihan Sampel

\begin{tabular}{clc}
\hline No & \multicolumn{1}{c}{ Keterangan } & Jumlah Perusahaan \\
\hline 1. & $\begin{array}{l}\text { Keseluruhan perusahaan transportasi yang tercatat di } \\
\text { Bursa Efek Indonesia (BEI) sepanjang tahun 2015-2019 } \\
\text { 2. }\end{array}$ & 45 \\
& $\begin{array}{l}\text { Perusahaan yang tidak tercatat secara berkala serta tidak } \\
\text { membuat laporan keuangan yang telah diaudit oleh auditor } \\
\text { independen sepanjang tahun 2015-2019 } \\
\text { Perusahaan sektor transportasi yang tercatat di Bursa Efek } \\
\text { Indonesia (BEI) tahun 2015-2019 }\end{array}$ & \multirow{2}{*}{30} \\
\hline & Total data untuk observasi (30 x 5 tahun) & 150 \\
\hline
\end{tabular}

Sumber : Data diolah, 2021

\section{Definisi Operasional Variabel Penelitian}

\section{Opini Audit Going Concern (Y)}

Opini going concern ialah opini yang diungkapkan auditor, yang isinya menekankan keraguan mengenai kesanggupan perusahaan untuk menjaga kelangsungan bisnis. Bersumber pada asumsi kelangsungan usaha, suatu entitas dianggap mampu menetap dalam bisnisnya untuk masa depan yang bisa diproyeksi (IAPI, 2013). OAGC digunakan sebagai lambang dari variabel ini dan variabel dummy digunakan sebagai pengukuran pada variabel ini. Diberi nilai 1 untuk perusahaan yang dalam laporan keuangannya didapati penekanan perihal opini audit going concern, kemudian diberi nilai 0 untuk perusahaan yang dalam laporan keuangannya tidak didapati penekanan perihal opini audit going concern.

\section{Restrukturisasi Hutang (X1)}

Satu dari banyak upaya yang dapat dilakukan oleh manajemen perusahaan untuk mengungkap rencana manajemen dalam menjaga kondisi perusahaan agar terbebas dari penerimaan opini audit going concern dari auditornya ialah dengan melakukan restrukturisasi hutang. Variabel ini dilambangkan dengan lambang REST dan diukur menggunakan variabel dummy, yang diidentifikasi dari apakah terdapat keterangan dalam CALK bahwasanya perusahaan melakukan restrukturisasi kredit. Jika terdapat indikasi restrukturisasi kredit maka diberi nilai 1, jika tidak terdapat indikasi restrukturisasi kredit maka diberi nilai 0 .

\section{Reputasi KAP (X2)}

Reputasi KAP merupakan seberapa baik kantor akuntan publik tersebut dalam menjalankan standar, kode etik, dan peraturan yang berlaku. Variabel ini dilambangkan dengan lambang RKAP dan diukur menggunakan variabel dummy, yang diidentifikasi dari apakah KAP pernah melanggar standar, kode etik, dan peraturan yang berlaku dan menjadi sanksi dalam PPPK Kementerian Keuangan Republik Indonesia. Jika KAP tidak pernah melakukan pelanggaran dan menyebabkan menjadi sanksi dalam PPPK Kementerian Keuangan Republik Indonesia, maka diberi nilai 1, jika KAP pernah melakukan pelanggaran dan menyebabkan menjadi sanksi dalam PPPK Kementerian Keuangan Republik Indonesia, diberi nilai 0. 


\section{JURNAL AKUNTANSI, Vol. 10, No. 2, November (2021)}

\section{Likuiditas (X3)}

Kapabilitas perusahaan dalam mengelola aset lancar yang dimiliki untuk melunasi utang jangka pendeknya mencerminkan likuiditas perusahaan. Likuiditas biasa diartikan sebagai current ratio dalam perusahaan. Current ratio merupakan perbandingan angka aset lancar dengan utang jangka pendek yang dimiliki perusahaan sebagai cerminan kapabilitas perusahaan dalam menjalankan operasional usahanya. Kemudian, variabel ini dilambangkan dengan lambang LIKD dan rumus current ratio yang digunakan sebagai berikut:

$$
\text { Current Ratio }=\frac{\text { Total Aset Lancar }}{\text { Total Utang Lancar }} \times 100 \%
$$

\section{Opinion Shopping (X4)}

Definisi opinion shopping oleh Komisi Sekuritas dan Bursa Amerika Serikat ialah bentuk aktivitas mencari auditor yang ingin menunjang kinerja manajemen dalam menjalankan proses akuntansi untuk mendapatkan tujuan pelaporan keuangan yang diinginkan. Umumnya, perusahaan melakukan peralihan auditor (auditor switching) dalam rangka agar terbebas dari penerimaan opini audit going concern. Hal ini dilakukan sebelum masa atau tenur perikatan yang telah ditetapkan oleh undang-undang selesai. Sehingga, apabila perusahaan tidak lagi mendapati opini audit going concern setelah mengganti auditornya maka perusahaan tersebut dinilai berhasil melakukan opinion shopping. Variabel ini dilambangkan dengan lambang OPSH dan variabel dummy digunakan sebagai pengukuran variabel ini. Bagi perusahaan yang diaudit oleh auditor independen lain pada tahun kedua seusai memperoleh opini audit going concern, nilainya 1 , sedangkan bagi perusahaan yang diaudit oleh auditor independen yang sama pada tahun berikutnya seusai perusahaan memperoleh opini audit going concern, nilainya 0 .

\section{Teknik Analisis Data}

Penelitian ini menggunakan teknik analisis data berupa statistik deskriptif serta pengujian hipotesis menggunakan uji regresi logistik. Ghozali (2011) menjelaskan bahwa statistik deskriptif memaparkan gambaran umum variabel dari perspektif nilai variabel, maksimum, rata-rata minimum (mean) dan standar deviasi. Variabel opini audit going concern dijelaskan sebagai variabel dependen, sedangkan restrukturisasi hutang, reputasi KAP, likuiditas, dan opinion shopping dijelaskan sebagai variabel independen. Sehingga diperoleh model regresi sebagai berikut:

$$
\ln \frac{O A G C}{1-O A G C}=\alpha+\beta_{1} R E S T+\beta_{2} R K A P+\beta_{2} L I K D+\beta_{4} O P S H+\varepsilon
$$

Keterangan :

OAGC : Opini audit going concern

REST : Restrukturisasi hutang

RKAP : Reputasi KAP

LIKD : Likuiditas

OPSH : Opinion shopping 


\section{HASIL DAN PEMBAHASAN}

\section{Analisis Statistik Deskriptif}

Tabel 3. Statistik Deskriptif

\begin{tabular}{lcccc}
\hline & $\boldsymbol{N}$ & Min & Max & Mean \\
\hline OAGC & 150 & 0.00 & 1.00 & 0.3200 \\
REST & 150 & 0.00 & 1.00 & 0.2267 \\
RKAP & 150 & 0.00 & 1.00 & 0.9467 \\
LIKD & 150 & 0.04 & 6.04 & 1.2245 \\
OPSH & 150 & 0.00 & 1.00 & 0.1000 \\
\hline
\end{tabular}

Sumber : Hasil olah data SPSS, 2021

Tabel 3 menguraikan bahwa nilai rata-rata variabel opini going concern, restrukturisasi hutang, dan opinion shopping berturut-turut yaitu 0.3200, 0.2267, dan 0.1000. Ketiga nilai tersebut $<0.50$ yang menunjukkan perusahaan penerima opini going concern, tidak melakukan restrukturisasi hutang, dan melakukan praktik opinion shopping lebih sedikit muncul. Dari 150 perusahaan terdapat 48 yang menerima opini going concern, 34 perusahaan melakukan restrukturisasi hutang dan 15 perusahaan melakukan praktik opinion shopping. Nilai minimum dari likuiditas ialah 0.04 sedangkan nilai maksimumnya 6.04 dengan rata-rata 1.2245. Variabel reputasi KAP mempunyai nilai rata-rata 0.9467 . Artinya nilai tersebut $<0.50$ yang menunjukkan sebanyak 142 perusahaan transportasi diaudit oleh KAP yang bereputasi baik.

\section{Analisis Regresi Logistik}

Uji Kelayakan Model (Hosmer and Lemeshow's Goodness of Fit Test)

Tabel 4. Hosmer And Lemeshow Fit Test

\begin{tabular}{cccc}
\hline Step & Chi-square & df & Sig. \\
\hline 1 & 8.530 & 8 & 0.383 \\
\hline \multicolumn{4}{l}{ Sumber $:$} \\
\hline
\end{tabular}

Hosmer and Lemeshow's Goodness of Fit test dikatakan fit dengan data ketika nilainya lebih besar dari $\alpha(0,05)$. Pengujian menunjukkan hasil nilai statistik $0,383>0,05$. Jadi, data sesuai dengan model regresi yang digunakan. 


\section{JURNAL AKUNTANSI, Vol. 10, No. 2, November (2021)}

\section{Uji Keseluruhan Model (Overall Model Fit Test)}

Tabel 5. Log Likelihood Awal

\begin{tabular}{cccc}
\hline Iteration & -2 Log likelihood & $\begin{array}{c}\text { Coefficients } \\
\text { Constant }\end{array}$ \\
\hline Step 0 & 1 & 188.098 & -0.720 \\
& 2 & 188.061 & -0.754 \\
& 3 & 188.061 & -0.754 \\
\hline
\end{tabular}

Sumber : Hasil olah data SPSS, 2021

Tabel 6. Log Likelihood Akhir

\begin{tabular}{rcc}
\hline Iteration & -2 Log likelyhood \\
\hline Step 1 & 1 & 160.167 \\
& 2 & 158.887 \\
3 & 158.872 \\
4 & 158.872 \\
5 & 158.872 \\
\hline
\end{tabular}

Sumber : Hasil olah data SPSS, 2021

Jika terjadi penyusutan antara nilai -2 Log Likelihood awal dan nilai -2 Log Likelihood akhir, model regresi akan lebih baik. Hasil pengujian menunjukkan bahwa nilai awal -2 Log Likelihood adalah 188.061, dan nilai terakhir -2 Log Loglihood adalah 158.872. Dapat disimpulkan bahwasanya data yang diolah cocok dengan model regresi yang dihipotesiskan.

\section{Uji Koefisien Determinasi (Nagelkerke R Square)}

Tabel 7. Nagelkerke R Square

\begin{tabular}{|c|c|c|}
\hline Step & -2 Log likelihood & Nagelkerke R Square \\
\hline 1 & $158.872^{\mathrm{a}}$ & 0.247 \\
\hline
\end{tabular}

Hasil pengujian menunjukkan nilai Nagelkerke $R$ Square yaitu 0,247 yang memaparkan bahwa variabel independen berupa restrukturisasi hutang, reputasi KAP, likuiditas, dan opinion shopping dapat memprediksi penerimaan opini audit going concern sebesar $24,7 \%$. 


\section{Model Regresi Logistik}

Tabel 8. Regresi Logistik

\begin{tabular}{|c|c|c|c|}
\hline & & B & Sig. \\
\hline \multirow[t]{5}{*}{ Step $1^{a}$} & REST & -1.677 & 0.000 \\
\hline & RKAP & 1.484 & 0.125 \\
\hline & LIKD & -0.228 & 0.218 \\
\hline & OPSH & -1.626 & 0.011 \\
\hline & Constant & 2.113 & 0.004 \\
\hline
\end{tabular}

Sumber : Hasil olah data SPSS, 2021

Berdasarkan hasil pengujian ini ditunjukkan bahwa variabel restrukturisasi hutang bernilai signifikasi sebesar 0.000 dan opinion shopping sebesar 0.011 yang mana keduanya mempunyai nilai signifikansi $<0.05$. Artinya, variabel tersebut berdampak terhadap didapatinya opini audit going concern. Sementara itu, nilai signifikansi variabel reputasi KAP adalah 0.125 dan nilai signifikansi likuiditas 0.218 . Nilai signifikansi kedua variabel tersebut $>0.05$ yang artinya variabel tersebut tidak memberi dampak terhadap didapatinya opini audit going concern. Adapun nilai konstanta yang terbentuk adalah 2.113 yang berarti opini going concern akan naik sebesar 2.113 apabila semua variabel independen dianggap konstan. Sehingga persamaan model regresinya adalah:

$$
\ln \frac{O A G C}{1-O A G C}=2.113-1.677 \text { REST }+1.484 \text { RKAP }-0.228 \text { LIKD }-1.6260 \text { PSH }+\varepsilon
$$

\section{Pembahasan}

\section{Pengaruh Restrukturisasi Hutang terhadap Opini Audit Going Concern}

Dari pengujian tersebut, hasil uji memaparkan bahwa restrukturisasi hutang berdampak pada didapatinya opini audit going concern, sehingga hipotesis diterima. Restrukturisasi hutang adalah satu dari banyak upaya yang dilakukan oleh manajemen perusahaan untuk mempertahankan kelangsungan usaha suatu perusahaan dalam keadaan dimana perusahaan tersebut tidak dapat melunasi kewajibannya sesuai dengan jatuh tempo. Hal ini dikarenakan perusahaan yang melakukan restrukturisasi hutang besar kemungkinan sedang mengalami financial distress, sehingga hal ini dapat mengganggu kelangsungan hidup perusahaan. Karena hal ini pula, berdampak pada pemberian opini audit going concern dari auditor.

Dengan begitu, penelitian mendukung teori agensi, yang mana agent memiliki kendali atas keuangan perusahaan termasuk dalam hal restrukturisasi hutang. Kinerja agent akan dilihat dari laba yang dihasilkan yang selanjutnya bisa digunakan untuk melunasi utang perusahaan. Akan tetapi, adanya inovasi model bisnis yang tidak bisa diikuti perusahaan serta lesunya perekonomian mengakibatkan menurunnya realisasi penjualan sehingga perusahaan mengalami kerugian. Kondisi ini mempengaruhi kemampuan perusahaan dalam membayarkan hutang yang dimiliki sesuai dengan jatuh tempo yang kemudian berakhir pada pemberian opini audit going concern.

Riset ini juga mendukung teori signaling, dimana restrukturisasi hutang merupakan sinyal bagi auditor dalam mengungkap opini audit going concern. Ditemukan beberapa data penelitian menunjukkan perusahaan berkode saham IATA, PTIS, SAFE, dan KARW melakukan restrukturisasi hutang selama 4 sampai 5 tahun berturut-turut dan menerima opini audit going concern. 


\section{JURNAL AKUNTANSI, Vol. 10, No. 2, November (2021)}

\section{Pengaruh Reputasi KAP terhadap Opini Audit Going Concern}

Hasil penelitan ini menunjukkan bahwa pemberian opini audit going concern tidak terdampak oleh reputasi KAP. Hasil ini sesuai dengan penelitian Tandungan (2016) dan Laksmiati \& Atiningsih (2018). Terbukti bahwa reputasi KAP tidak berdampak pada opini audit going concern, sehingga hipotesis ditolak.

Output dari penelitian ini menjelaskan bahwa reputasi KAP dapat mencerminkan kualitas kinerja KAP serta meningkatkan value sebuah KAP di stakeholder. Reputasi KAP ini memang penting, karena perihal tersebut dapat meningkatkan kualitas audit serta kepercayaan dari klien (manajemen perusahaan) atas pertanggungjawaban opini yang akan dikeluarkan oleh auditornya. Namun, reputasi KAP yang pernah maupun tidak pernah terlibat sanksi atau pelanggaran oleh Kementerian Keuangan RI tidak memberi dampak dalam pemberian opini audit going concern. Karenakan pada dasarnya, dalam pemberian opini auditor telah diatur dalam Standar Akuntansi Sektor Publik yang berlaku dan harus dipatuhi sebagai standar etika profesi auditor itu sendiri. Professional judgement yang dimiliki oleh setiap auditor sehingga pemberian opini audit going concern merupakan kewajiban yang harus diungkapkan oleh setiap auditor, baik dari KAP yang bereputasi baik maupun tidak, terkait dengan kondisi keberlangsungan perusahaan yang sesungguhnya. Dalam lingkup sektor perusahaan transportasi, terdapat 24 perusahaan yang diaudit oleh auditor dari KAP yang bereputasi baik. Sedangkan, sekitar 6 perusahaan diaudit oleh auditor dari KAP yang pernah terkena sanksi pelanggaran oleh Kemenkeu RI dan tetap dapat mengeluarkan opini audit going concern kepada perusahaan tersebut apabila memang kondisi perusahaan diragukan kelangsungan hidupnya, satu diantaranya yaitu perusahaan dengan kode saham GIAA.

\section{Pengaruh Likuiditas terhadap Opini Audit Going Concern}

Hasil penelitian ini sesuai dengan hasil penelitian Anita (2017) dan Made, dkk (2017) yang menjelaskan likuiditas tidak berdampak pada opini audit going concern. Pengujian data yang telah peneliti lakukan membuktikan likuiditas tidak berdampak pada opini audit going concern, sehingga hipotesis ditolak.

Output dari penelitian ini memaparkan bahwa apabila rasio likuiditas tinggi maka perusahaan dianggap sehat. Oleh sebab itu, perusahaan dengan rasio likuiditas yang rendah patut curiga terhadap kesinambungan usahanya di kemudian hari, karena hal tersebut akan mempengaruhi reputasi perusahaan dan kemungkinan besar dapat memperoleh opini audit going concern. Namun, faktanya ketika opini audit going concern dikeluarkan oleh auditor, mereka tidak selalu meninjau apakah perusahaan mampu melunasi utang jangka pendeknya dengan mempertimbangkan total aset lancar perusahaan. Auditor lebih mementingkan pada kapabilitas perusahaan dalam menuntaskan utang-hutangnya secara keseluruhan. Misalnya, ketika menganalisis kinerja perusahaan yang diaudit, mereka meninjau keseluruhan hutang yang dimiliki perusahaan dengan melihat prospek yang realistis dalam pelunasannya dan kerugian operasional yang substansial. Dalam sektor transportasi, likuiditas tidak berpengaruh dikarenakan aset tetap yang dimiliki perusahaan berjumlah lebih besar dari jumlah aset lancarnya. Oleh sebab itu, mayoritas kontrak yang dibuat perusahaan lebih kepada jangka panjang dibanding jangka pendek. Angka rasio likuiditas pada perusahaan transportasi ini juga mayoritas dibawah 1,00 walaupun tetap tidak menerima opini audit going concern. Karenanya, dalam pemberian opini audit going concern bisa dipengaruhi oleh variabel lain yang bukan tertera dalam penelitian ini. 


\section{JURNAL AKUNTANSI, Vol. 10, No. 2, November (2021)}

\section{Pengaruh Opinion Shopping terhadap Opini Audit Going Concern}

Opini audit going concern dapat dipengaruhi oleh opinion shopping menurut penelitian Syahputra \& Yahya (2017). Sesuai dengan output pengujian penelitian ini yang juga menunjukkan opini audit going concern dapat terdampak oleh opinion shopping, sehingga hipotesis diterima.

Hal ini menegaskan apabila opini audit going concern yang diterima di tahun yang akan datang dapat dipengaruhi oleh peralihan auditor perusahaan yang sebelumnya memberikan opini audit going concern. Output penelitian ini juga mendukung teori signaling, dimana ketika perusahaan memiliki peluang yang besar akan didapati auditornya mengeluarkan opini audit going concern, manajemen perusahaan dapat berupaya untuk melakukan opinion shopping dengan mengganti auditornya. Ini merupakan sinyal bagi manajemen perusahaan agar tidak lagi mendapati auditor yang telah diganti mengeluarkan opini audit going concern. Terdapat beberapa data penelitian menunjukkan perusahaan berkode saham WEHA dan INDX yang melakukan opinion shopping dan kemudian di tahun berikutnya tidak menerima opini audit going concern.

\section{PENUTUP}

\section{Simpulan}

Simpulan dari hasil penelitian ini adalah bahwa terdapat dua variabel dalam penelitian ini yang memberi dampak pada pemberian opini audit going concern yaitu opinion shopping dan restrukturisasi hutang. Restrukturisasi hutang yang dilakukan oleh perusahaan memungkinkan perusahaan mendapati opini audit going concern karena perusahaan dinilai tidak dapat melunasi kewajibannya sesuai dengan jatuh tempo. Perusahaan yang mendapati opini audit going concern, juga condong akan melakukan praktik opinion shopping yang mana dapat berdampak pada penerimaan opini di tahun selanjutnya. Sedangkan, dua variabel lainnya yaitu reputasi KAP dan likuiditas tidak berdampak dalam pemberian opini audit going concern. Walaupun likuiditas dapat mengindikasi kinerja perusahaan, namun faktanya ketika auditor mengeluarkan opini audit going concern, mereka tidak hanya mempertimbangkan rasio likuiditasnya saja. Auditor lebih mementingkan pada kapabilitas perusahaan dalam menuntaskan utang-hutangnya secara keseluruhan. Misalnya, ketika menganalisis kinerja perusahaan yang diaudit, mereka meninjau keseluruhan hutang yang dimiliki perusahaan dengan melihat prospek yang realistis dalam pelunasannya dan kerugian operasional yang substansial. Terutama dalam sektor transportasi , aset tetap perusahaan lebih besar dari jumlah total aset lancar yang dimilikinya. Oleh karena itu, sebagian besar kontrak yang ditandatangani oleh perusahaan lebih bersifat jangka panjang daripada jangka pendek. Sementara reputasi KAP juga tidak berdampak pada opini audit going concern. Proxy reputasi KAP ini telah diganti dari peneliti-peneliti sebelumnya, dimana peneliti sebelumnya memproksikan dengan apakah KAP termasuk Big Four atau tidak. Sedangkan, reputasi KAP dalam penelitian ini diproksikan dengan pernah tidaknya seorang auditor didalam suatu KAP melakukan sanksi atau pelanggaran oleh Kementerian Keuangan RI.

\section{Saran}

Proxy reputasi KAP pada penelitian ini telah diganti dari peneliti-peneliti sebelumnya, dimana peneliti sebelumnya memproksikan reputasi KAP dengan apakah KAP termasuk Big Four atau tidak. Sedangkan, reputasi KAP dalam penelitian ini diproksikan dengan pernah tidaknya seorang auditor didalam suatu KAP melakukan sanksi atau pelanggaran oleh Kementerian Keuangan RI. Saran untuk peneliti berikutnya, mengimprovisasi proxy dengan hal yang baru sesuai dengan kebutuhan penelitian di masa mendatang. 


\section{JURNAL AKUNTANSI, Vol. 10, No. 2, November (2021)}

Keterbatasan penulis dalam penelitian ini dikarenakan hanya mencakup perusahaan transportasi karena melihat dari latar belakang yaitu kemajuan teknologi yang terjadi pada tahun 2015-2019 yang menyebabkan maraknya penggunaan transportasi secara online. Saran untuk peneliti selanjutnya, bisa menggunakan obyek penelitian yang sama namun di tahun yang berbeda seperti di keadaan tahun 2020 dan 2021 yang mana terjadi munculnya virus Corona (COVID-19) yang mungkin menyebabkan penurunan pendapatan perusahaan transportasi akibat adanya social distancing dan PSBB (Pembatasan Sosial Berskala Besar) atau malah meningkat karena maraknya belanja online.

\section{REFERENSI}

Anita, W. F. (2017). Analisis Faktor-Faktor Yang Mempengaruhi Opini Audit Going Concern Pada Perusahaan Manufaktur Yang Terdaftar Di Bursa Efek Indonesia. Jurnal Riset Keuangan Dan Akuntansi, 3(2), 87-108. https://doi.org/10.25134/jrka.v3i2.939

CNBCIndonesia.com. (2020). Bandel! 26 Emiten Telat Setor Lapkeu 2019, Kena Suspensi Deh. https://www.cnbcindonesia.com/market/20200831113604-17-183224/bandel-26-emitentelat-setor-lapkeu-2019-kena-suspensi-deh

CNNIndonesia.com. (2019). Jurus Blue Bird Bersaing dengan Taksi Online. https://www.cnnindonesia.com/teknologi/20191022164108-185-441856/jurus-blue-birdbersaing-dengan-taksi-online

Connelly, B. L., Certo, S. T., Ireland, R. D., \& Reutzel, C. R. (2011). Signaling theory: A review and assessment. Journal of Management, 37(1), 39-67. https://doi.org/10.1177/0149206310388419

Debby Tandungan, I. M. M. (2016). E-Jurnal Akuntansi Universitas Udayana Pengaruh Komite Audit, Ukuran Perusahaan, Audit Tenure, Dan Reputasi Kap Terhadap Opini Audit Going Concern. Fakultas Ekonomi dan Bisnis Universitas Udayana ( Unud ), BaliIndonesia Fakultas Ekonomi dan Bisnis Univ. 16, 45-71.

Detik.com. (2017). Awal Mula Transportasi Online Menjamur di Indonesia. https://inet.detik.com/cyberlife/d-3609781/awal-mula-transportasi-online-menjamur-diindonesia

Elmawati, D., Nur, E., Yuyetta, A., Akuntansi, J., Ekonomika, F., \& Diponegoro, U. (2014). Pengaruh Reputasi Kantor Akuntan Publik (Kap), Audit Tenure, Dan Disclosure Terhadap Penerimaan Opini Audit Going Concern. 3(2), 415-424.

Ghozali, I. (2011). Aplikasi Analisis Multivariate dengan Program SPSS.

Handke, L., \& Barthauer, L. (2019). Heider, Fritz (1958): 1958, 259-260.

IAPI. (2013). SA 570.pdf (pp. 1-16).

Jensen, C., \& Meckling, H. (1976). Theory Of The Firm: Managerial Behavior, Agency Costs And Ownership Structure I. Introduction and summary In this paper WC draw on recent progress in the theory of $(1)$ property rights, firm. In addition to tying together elements of the theory of e. 3, 305-360.

Kontan.co.id. (2019). No TitleSebanyak 11 Emiten Kena Suspensi Karena Belum Bayar Biaya Pencatatan. https://investasi.kontan.co.id/news/sebanyak-11-emiten-kena-suspensikarena-belum-bayar-biaya-pencatatan

Krissindiastuti, M., \& Rasmini, N. K. (2016). E-Jurnal Akuntansi Universitas Udayana FaktorFaktor Yang Mempengaruhi Opini Audit Going Concern Fakultas Ekonomi dan Bisnis Universitas Udayana ( Unud ), Bali, Indonesia Fakultas Ekonomi dan Bisnis Universitas 


\section{JURNAL AKUNTANSI, Vol. 10, No. 2, November (2021)}

Udayana ( Unud ), Bali, Indonesia ABSTRAK . 14, 451-481.

Laksmiati, E. D., \& Atiningsih, S. (2018). Pengaruh Auditor Switching, Reputasi Kap Dan Financial Distress Terhadap Opini Audit Going Concern. E-Jurnal Akuntansi, 13(1), 4561.

Made, N., Yuliyani, A., Made, N., \& Erawati, A. (2017). E-Jurnal Akuntansi Universitas Udayana Pengaruh Financial Distress, Profitabilitas, Leverage Dan Likuiditaspada Opini Audit Going Concern Fakultas Ekonomi dan Bisnis Universitas Udayana ( Unud ), Bali , Indonesia Fakultas Ekonomi dan Bisnis Universitas . 19, 1490-1520.

Maharani, N. K. (2016). Kualitas Audit, Opini Audit Tahun Sebelumnya, Prediksi Kebangkrutan, Pertumbuhan Faktor Penyebab Timbulnya Opini Auditor Tentang Going Concern. 13(September).

Odanga, H. (2016). the Impact of Audit Firm Tenure, Client Importance and Auditor Reputation on Audit Quality: Evidence From Listed Firms in Kenya. November.

PT Bursa Efek Indonesia. (n.d.). Laporan Keuangan dan Tahunan Perusahaan Transportasi tahun 2015, 2016, 2017, 2018, 2019. https://www.idx.co.id/perusahaan-tercatat/laporankeuangan-dan-tahunan/

Putra, W., \& Suzan, L. (2013). Pengaruh Pertumbuhan Perusahaan, Opinion Shopping, Dan Prior Opinion Terhadap Penerimaan Opini Audit Going Concern ( Studi Pada Perusahaan Property and Real Estate yang Listing di BEI Tahun 2009-2013 ) The Influence Of Company Growth, Opinion Shopping . 2(2), 1683-1690.

Stanišić, N., Petrović, Z., Vićentijević, K., \& Mizdraković, V. (2014). Auditor Switching and Qualified Audit Opinion: Evidence from Serbia. 552-558. https://doi.org/10.15308/sinteza-2014-552-558

Syahputra, F., \& Yahya, M. R. (2017). Pengaruh Audit Tenure, Audit Delay, Opini Audit Tahun Sebelumnya dan Opinion Shopping Terhadap Penerimaan Opini Audit Going Concern pada Perusahaan Manufaktur yang Terdaftar di Bursa Efek Indonesia Tahun 2013-2015. Jurnal Ilmiah Mahasiswa Ekonomi Akuntansi (JIMEKA), 2(3), 2-9.

Trisnawati, A. S. dan R. (2014). Analisis Faktor-Faktor Yang Mempengaruhi Auditor Dalam Memberikan Opini Audit Going Concern Soliyah Wulandari UIN Syarif Hidayatullah Jakarta Pendahuluan Salah satu bentuk pertanggungjawaban manajemen kepada masyarakat, khususnya para pemegang saham adal. 3, 531-558.

WartaEkonomi.co.id. (2019). Ini Dampak Perkembangan E-Commerce bagi Indonesia. https://www.wartaekonomi.co.id/read216033/ini-dampak-perkembangan-e-commercebagi-indonesia 